\title{
molecules
}

ISSN 1420-3049

(C) 2008 by MDPI

www.mdpi.org/molecules

Full Paper

\section{Synthesis and Structural Analysis of Polyester Prodrugs of Norfloxacin}

\section{Marcin Sobczak*, Ewa Witkowska, Ewa Olędzka and Waclaw Kolodziejski}

Medical University of Warsaw, Faculty of Pharmacy, Department of Inorganic and Analytical Chemistry, ul. Banacha 1, 02-097 Warsaw, Poland; E-mails: dr.witt@wp.pl (E. Witkowska), eoledzka@wp.pl (E. Olędzka), waclaw@farm.amwaw.edu.pl (W. Kolodziejski)

* Author to whom correspondence should be addressed; E-mail: marcin.sobczak@wp.pl; Tel.: +48 22 57207 55; Fax: +48 225720784.

Received: 14 December 2007; in revised form: 16 January 2008 / Accepted: 16 January 2008 / Published: 18 January 2008

\begin{abstract}
Two-, three- and four-arm, star-shaped poly(E-caprolactone) and poly $(D, L$-lactide) homopolymers, and copolymers of $\varepsilon$-caprolactone with $D, L$-lactide were synthesized via ring-opening polymerization of cyclic esters in the presence of glycerol, penthaerythritol and poly(ethylene glycol) as initiators and stannous octoate as a catalyst. Thus obtained oligomers were successfully used in the synthesis of novel macromolecular prodrugs of norfloxacin. The structures of the polymers and prodrugs were elucidated by means of MALDI-TOF MS, NMR and IR studies.
\end{abstract}

Keywords: aliphatic polyesters, ring-opening polymerization, macromolecular prodrugs, prodrugs of norfloxacin.

\section{Introduction}

Pharmacy is one of the most important areas of application of polymers. They are used as active macromolecular pharmaceutical substances, blood substitutes, auxiliary materials and excipients, in production of macromolecular prodrugs, polymeric drug delivery systems, therapeutic systems, etc. The polymeric prodrugs, drug delivery systems and therapeutic systems exhibit unique pharmacokinetics, body distribution and pharmacological efficacy [1-12]. Biodegradable polymers like polylactide (PLA), poly( $\varepsilon$-caprolactone) (PCL) and copolymers of lactides (LA) and $\varepsilon$-caprolactone 
(CL) are very often used as drug delivery systems. Aliphatic polyesters are usually prepared by ringopening polymerization (ROP) of the corresponding cyclic monomers, that is $D, L-L A, L, L-L A$ or CL. PLA and PCL can be efficiently obtained by ROP in the presence of ionic initiators as well as coordinative and enzymatic catalysts [13-28].

Fluoroquinolones are an important new class of synthetic oral antibacterial agents used against various infections. They work by killing bacteria or preventing their growth. The first discovered and clinically effective quinolone was norfloxacin, that is 1-ethyl-6-fluoro-1,4-dihydro-4-oxo-7(1-piperazinyl)-3-quinolinecarboxylic acid [29]. Recently, the interaction of norfloxacin with DNA has been considered as useful in the anticancer drug design [30]. Preliminary efforts to prepare nanoparticles of poly $(D, L$-lactide-co-glycolide) loaded with adsorbed norfloxacin has already been reported [31]. The anticancer selectivity of norfloxacin is supposed to be improved by anchoring the drug using chemical linkage to biodegradable oligomers, which may transport the drug molecules more efficiently and more specifically. We go in the latter scientific direction.

In this paper, we describe the synthesis of a series of star-branched polyester prodrugs of norfloxacin. Chemical structures of the synthesized polymers have been confirmed by ${ }^{1} \mathrm{H}$ - and ${ }^{13} \mathrm{C}$ solution NMR as well as FT-IR spectroscopy. Absolute molecular weights of polymers have been determined using gel permeation chromatography (GPC), end-group analysis and matrix-assisted laser desorption/ionization time-of-flight mass spectrometry (MALDI-TOF MS).

\section{Results and Discussion}

The homo- and copolymerisation reactions of CL and LA were carried out in the presence of initiators like glycerol (Gl), penthaerythritol (Pet) or poly(ethylene glycol) (PEG), and stannous octoate $\left(\mathrm{SnOct}_{2}\right)$ as catalyst. Reaction conditions, yields and average molecular weight of obtained polyesters are summarized in Table 1. Under these conditions, cyclic monomers underwent ROP and the low-molecular weight polyesters with chain-end hydroxyl groups were obtained. The synthesized PCL and PLA polymers, and the CL\&LA copolymers had two-, three- and four-arm star shapes. A typical reaction scheme is presented in Scheme 1.

Scheme 1. Synthesis scheme for two-, three- and four-arm, star-shaped oligoesters.

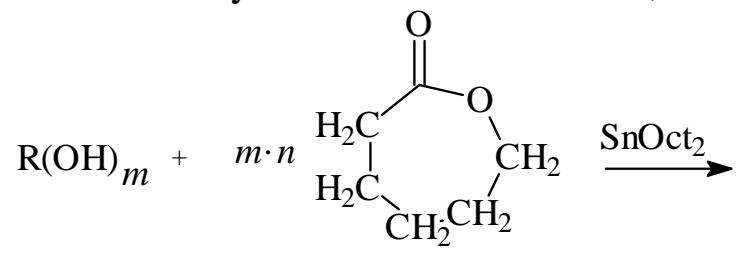

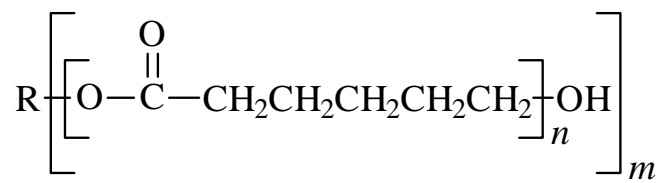

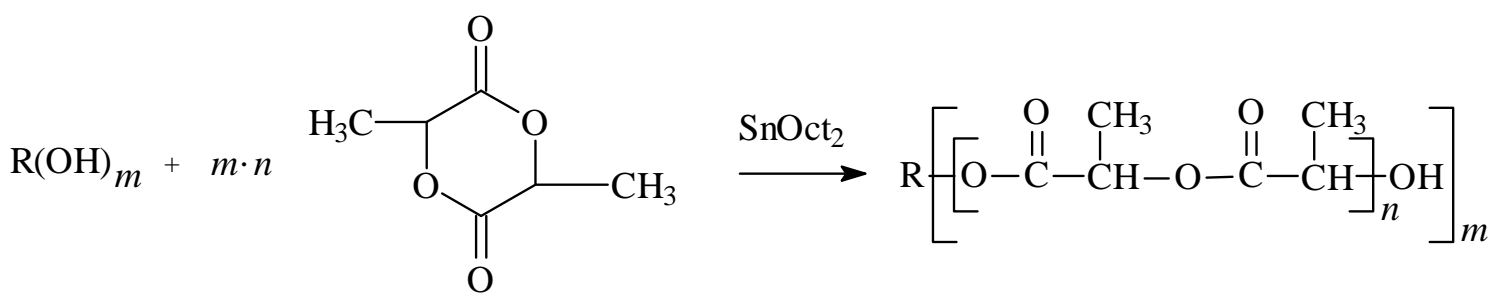
$\mathrm{m}=2$ (for poly(ethylene glycol)), 3 (for glycerol), 4 (penthaerythritol) 
Two-, three- and four-arm hydroxyl terminated oligomers were prepared using PEG, Gl and Pet initiators, respectively. The respective reaction yields were in the 79-100, 50-100 and 44-62 \% range. Thus, the polymerization yields were dependent on the type of the initiator. PEG was found to be more effective than Gl and Pet. For the CL and LA homopolymers, the number-average molecular weights determined by GPC were in the range 5200-9600 and 4200-8400 Da, respectively, while for the LA\&CL copolymer they were in the range 2900-3900 Da. PCL had higher molecular weights than PLA, and the homopolymers had higher molecular weights than the copolymers. In all cases, the polydispersity indexes were within 1.1-1.3 limits.

Table 1. Homopolymerization and copolymerization of CL and LA in the presence of various initiators and $\mathrm{SnOct}_{2}$.

\begin{tabular}{|c|c|c|c|c|c|c|c|c|c|c|}
\hline $\begin{array}{c}\text { Monomer(s) } \\
\text { /initiator/catalyst }\end{array}$ & M/I/Cat & $\begin{array}{c}\text { Yield } \\
(\%)\end{array}$ & $\begin{array}{l}\text { Phys. } \\
\text { form }\end{array}$ & $\begin{array}{c}M^{\mathrm{GPC}} \\
\text { (Da) }\end{array}$ & $\mathbf{P D}^{\mathrm{GPC}}$ & $\begin{array}{c}M \mathbf{n}^{\mathrm{MS}} \\
(\mathrm{Da})\end{array}$ & $\mathbf{P D}^{\mathrm{MS}}$ & $M n^{\text {th }}$ & $\begin{array}{c}M \mathbf{n}^{\mathrm{ar}} \\
\mathbf{m}\end{array}$ & cLA \\
\hline $\mathrm{CL} / \mathrm{PEG} / \mathrm{SnOct}_{2}$ & 100:2:1 & $\approx 100$ & ss & 5200 & 1.2 & 2500 & 1.2 & 6100 & 2600 & - \\
\hline $\mathrm{CL} / \mathrm{Gl} / \mathrm{SnOct}_{2}$ & 150:1.5:1 & $\approx 100$ & ss & 9600 & 1.3 & - & - & 11492 & 3200 & - \\
\hline $\mathrm{CL} / \mathrm{Pet} / \mathrm{SnOct}_{2}$ & 200:2:1 & 62 & ss & 5300 & 1.3 & 1900 & 1.1 & 7204 & 1300 & - \\
\hline $\mathrm{LA} / \mathrm{PEG} / \mathrm{SnOct}_{2}$ & $100: 2: 1$ & 79 & $\mathrm{vl}$ & 4200 & 1.2 & 1400 & 1.1 & 6088 & 2100 & - \\
\hline $\mathrm{LA} / \mathrm{Gl} / \mathrm{SnOct}_{2}$ & 150:1.5:1 & 65 & $\mathrm{vl}$ & 8400 & 1.3 & - & - & 9452 & 2800 & - \\
\hline $\mathrm{LA} / \mathrm{Pet} / \mathrm{SnOct}_{2}$ & 200:2:1 & 44 & $\mathrm{vl}$ & 5100 & 1.2 & 1600 & 1.2 & 6472 & 1300 & - \\
\hline LA\&CL/PEG/SnOct ${ }_{2}$ & 50:50:2:1 & 92 & $\mathrm{vl}$ & 3900 & 1.2 & - & - & 3277 & 2000 & 37 \\
\hline LA\&CL/Gl/SnOct ${ }_{2}$ & $75: 75: 1.5: 1$ & 50 & $\mathrm{vl}$ & 2900 & 1.1 & - & - & 3205 & 1000 & 35 \\
\hline LA\&CL/Pet/SnOct ${ }_{2}$ & 100:100:2:1 & 45 & $\mathrm{vl}$ & 3100 & 1.2 & - & - & 2690 & 800 & 44 \\
\hline
\end{tabular}

Reaction conditions: temp. of $120^{\circ} \mathrm{C}$, time $-48 \mathrm{~h}$

$M n^{\mathrm{GPC}}$ - number-average molecular weight determined by GPC

$\mathrm{PD}^{\mathrm{GPC}}$ - polydispersity ( $\mathrm{Mw} / \mathrm{Mn}$ ) determined by GPC

$M \mathrm{n}^{\mathrm{MS}}$ - number-average molecular weight determined by MALDI-TOF

$\mathrm{PD}^{\mathrm{MS}}$ - polydispersity (Mw/Mn) determined by MALDI-TOF

$M \mathrm{n}^{\text {th }}$ - theoretical number-average molecular weight of polymer.

For homopolymers: $M \mathrm{n}^{\text {th }}=[\mathrm{M}] /[\mathrm{I}] \times \mathrm{M}_{\text {monomer }} \times$ yield $+\mathrm{M}_{\text {initiator }}$.

For copolymers: $\mathrm{Mn}^{\text {th }}=[\mathrm{M}] /[\mathrm{I}] \times \mathrm{M}_{\text {comonomer(LA) }} \times$ yield $\times \mathrm{CLA}+[\mathrm{M}] /[\mathrm{I}] \times \mathrm{M}_{\text {comonomer(CL) }} \times$ yield $\times \mathrm{cCL}+$ $\mathrm{M}_{\text {initiator }}$

$M \mathrm{n}^{\mathrm{arm}}$ - number-average molecular weight of arm of PCL or PLA, $M \mathrm{n}^{\mathrm{arm}}=M \mathrm{n}^{\mathrm{GPC}} /$ oligomer arm number cLA - content of the LA units in the copolymer (mol \%), calculated from ${ }^{1} \mathrm{H}$ NMR on the basis of the intensity ratio of the main-chain $[-\mathrm{C}(\mathrm{O}) \mathrm{CH}(\mathrm{CH}) \mathrm{O}-]$ peak of PLA and the main-chain [$\left.\mathrm{CH}_{2} \mathrm{CH}_{2} \mathrm{CH}_{2} \mathrm{CH}_{2} \mathrm{CH}_{2} \mathrm{OC}(\mathrm{O})-\right]$ peak of PCL

cCL - content of the CL units in the copolymer (mol \%): cCL = $100-\mathrm{cLA}$

ss - sticky solid

$\mathrm{vl}$ - viscous liquid

The chemical structures of the obtained polymers were confirmed by ${ }^{1} \mathrm{H}-,{ }^{13} \mathrm{C}-\mathrm{NMR}$ and IR studies (Table 2). A typical ${ }^{1} \mathrm{H}-\mathrm{NMR}$ spectrum of the two-armed PCL is shown in Figure 1. 
Table 2. ${ }^{1} \mathrm{H}$ - and ${ }^{13} \mathrm{C}-\mathrm{NMR}\left(\mathrm{CDCl}_{3}, \delta\right.$, ppm) peak assignments and the main IR absorption bands $\left(\mathrm{KBr}, \mathrm{cm}^{-1}\right)$ of the obtained polymers.

\section{PCL-PEG:}

${ }^{1} \mathrm{H}-\mathrm{NMR}: 4.20$ (2H, CL-OCH $\left.\mathrm{CH}_{2} \mathrm{O}-\right), 4.01$ (2H, t, $\left.-\mathrm{CH}_{2} \mathrm{CH}_{2} \mathrm{OC}(\mathrm{O})-\right), 3.70$ (2H, t, $-\mathrm{CH}_{2} \mathrm{CH}_{2} \mathrm{OH}$, end group), $3.66\left(2 \mathrm{H}, \mathrm{t},-\mathrm{OCH}_{2} \mathrm{CH}_{2} \mathrm{O}-\right), 2.24$ (2H, t, $\left.-\mathrm{CH}_{2} \mathrm{CH}_{2} \mathrm{COO}-\right), 1.58\left(4 \mathrm{H}, \mathrm{m},-\mathrm{CH}_{2} \mathrm{CH}_{2} \mathrm{COO}-\right)$, 1.33 (2H, m, $\left.-\mathrm{CH}_{2} \mathrm{CH}_{2} \mathrm{CH}_{2} \mathrm{CH}_{2} \mathrm{CH}_{2}-\right)$

${ }^{13} \mathrm{C}-\mathrm{NMR}: 173.1$ (-C(O)O-), 70.1 (-OCH$\left.{ }_{2} \mathrm{CH}_{2} \mathrm{O}-\right)$ ), 64.1 (CL-OCH $\left.\mathrm{CH}_{2} \mathrm{O}-\right), 63.7\left(-\mathrm{CH}_{2} \mathrm{CH}_{2} \mathrm{OC}(\mathrm{O})-\right), 33.6$ (- $\left.\mathrm{CH}_{2} \mathrm{CH}_{2} \mathrm{COO}-\right), 27.9$ (- $\left.\mathrm{CH}_{2} \mathrm{CH}_{2} \mathrm{OC}(\mathrm{O})-\right), 25.1$ (- $\left.\mathrm{CH}_{2} \mathrm{CH}_{2} \mathrm{COO}-\right), 24.1\left(-\mathrm{CH}_{2} \mathrm{CH}_{2} \mathbf{C H}_{2} \mathrm{CH}_{2} \mathrm{CH}_{2}-\right)$

FTIR: $2943\left(v_{\mathrm{as}} \mathrm{CH}_{2}\right), 2862\left(v_{\mathrm{s}} \mathrm{CH}_{2}\right), 1721(v \mathrm{C}=\mathrm{O}), 1291$ (C-O and C-C) $1240\left(v_{\mathrm{as}} \mathrm{COC}\right), 1190$ (vOC-O), 1170 $\left(v_{\mathrm{s}} \mathrm{COC}\right), 1157$ (C-O and C-C)

\section{PCL-Gl:}

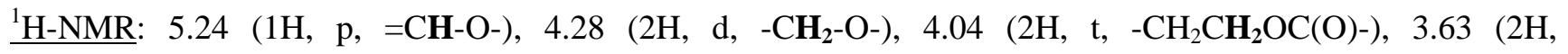
$\mathrm{t}$, $-\mathrm{CH}_{2} \mathrm{CH}_{2} \mathrm{OH}$, end group), $2.28\left(2 \mathrm{H}, \mathrm{t},-\mathrm{CH}_{2} \mathrm{CH}_{2} \mathrm{COO}-\right), 1.62\left(4 \mathrm{H}, \mathrm{m},-\mathrm{CH}_{2} \mathrm{CH}_{2} \mathrm{COO}-\right), 1.35$ (2H, m, $\left.-\mathrm{CH}_{2} \mathrm{CH}_{2} \mathrm{CH}_{2} \mathrm{CH}_{2} \mathrm{CH}_{2}-\right)$

${ }^{13} \mathrm{C}-\mathrm{NMR}: 173.1 \quad(-\mathrm{C}(\mathrm{O}) \mathrm{O}-), 63.7 \quad\left(-\mathrm{CH}_{2} \mathrm{CH}_{2} \mathrm{OC}(\mathrm{O})-\right), 62.1 \quad\left(-\mathrm{CH}_{2}-\mathrm{O}-\right), \quad 33.6 \quad\left(-\mathrm{CH}_{2} \mathrm{CH}_{2} \mathrm{COO}-\right), 27.9$ $\left(-\mathrm{CH}_{2} \mathrm{CH}_{2} \mathrm{OC}(\mathrm{O})-\right), 25.1\left(-\mathrm{CH}_{2} \mathrm{CH}_{2} \mathrm{COO}-\right), 24.1\left(-\mathrm{CH}_{2} \mathrm{CH}_{2} \mathrm{CH}_{2} \mathrm{CH}_{2} \mathrm{CH}_{2}-\right)$

FTIR: $2949\left(v_{\text {as }} \mathrm{CH}_{2}\right), 2865\left(v_{\mathrm{s}} \mathrm{CH}_{2}\right), 1727$ (vC=O), 1293 (C-O and C-C), 1240 (vas $\left.\mathrm{COC}\right), 1190$ (vOC-O), 1170 $\left(v_{\mathrm{s}} \mathrm{COC}\right)$

\section{PCL-Pet:}

${ }^{1} \mathrm{H}-\mathrm{NMR}: 4.02$ (2H, t, - $\left.\mathrm{CH}_{2} \mathrm{CH}_{2} \mathrm{OC}(\mathrm{O})-\right), 3.60$ (2H, t, $-\mathrm{CH}_{2} \mathrm{CH}_{2} \mathrm{OH}$, end group), 2.25 (2H, t, $\left.-\mathrm{CH}_{2} \mathrm{CH} \mathbf{H}_{2} \mathrm{COO}-\right)$, 1.59 (4H, m, - $\left.\mathrm{CH}_{2} \mathrm{CH}_{2} \mathrm{COO}-\right)$, 1.34 (2H, m, $\left.-\mathrm{CH}_{2} \mathrm{CH}_{2} \mathrm{CH}_{2} \mathrm{CH}_{2} \mathrm{CH}_{2}-\right)$

${ }^{13} \mathrm{C}-\mathrm{NMR}: 173.1 \quad(-\mathrm{C}(\mathrm{O}) \mathrm{O}-), 63.7 \quad\left(-\mathrm{CH}_{2} \mathrm{CH}_{2} \mathrm{OC}(\mathrm{O})-\right), 63.4 \quad\left(\mathrm{C}-\mathrm{CH}_{2} \mathrm{O}-\right), \quad 33.6 \quad\left(-\mathrm{CH}_{2} \mathrm{CH}_{2} \mathrm{COO}-\right), \quad 33.3$ (C-CH $2 \mathrm{O}-)$, 27.9 (- $\left.\mathrm{CH}_{2} \mathrm{CH}_{2} \mathrm{OC}(\mathrm{O})-\right), 25.1$ (- $\left.\mathrm{CH}_{2} \mathrm{CH}_{2} \mathrm{COO}-\right)$, $24.1\left(-\mathrm{CH}_{2} \mathrm{CH}_{2} \mathrm{CH}_{2} \mathrm{CH}_{2} \mathrm{CH}_{2}-\right)$

FTIR: $2948\left(v_{\text {as }} \mathrm{CH}_{2}\right), 2864\left(v_{\mathrm{s}} \mathrm{CH}_{2}\right), 1726$ (vC=O), 1293 (C-O and C-C), 1238 (vas $\left.\mathrm{COC}\right), 1189$ (vOC-O), 1169 $\left(v_{\mathrm{s}} \mathrm{COC}\right)$

\section{PLA-PEG:}

${ }^{1} \mathrm{H}-\mathrm{NMR}: 5.17\left(1 \mathrm{H}, \mathrm{q},-\mathrm{CH}\left(\mathrm{CH}_{3}\right)-\right), 4.36\left(1 \mathrm{H}, \mathrm{q},-\mathrm{CH}\left(\mathrm{CH}_{3}\right) \mathrm{OH}\right.$, end group), 4.25 (2H, LA-OCH $\left.\mathrm{CH}_{2} \mathrm{O}-\right)$, 3.61 $\left(2 \mathrm{H}, \mathrm{t},-\mathrm{OCH}_{2} \mathrm{CH}_{2} \mathrm{O}-\right), 1.58\left(3 \mathrm{H}, \mathrm{d},-\mathrm{CH}_{3}\right)$

${ }^{13} \mathrm{C}-\mathrm{NMR}: 169.8$ (-C(O)O-), $69.2\left(-\mathrm{CH}\left(\mathrm{CH}_{3}\right)-\right), 16.8\left(-\mathrm{CH}_{3}\right)$.

FTIR: $2997\left(v_{\mathrm{as}} \mathrm{CH}_{3}\right), 2947\left(v_{\mathrm{s}} \mathrm{CH}_{3}\right), 2882(v \mathrm{CH}), 1760(v \mathrm{C}=\mathrm{O}), 1452\left(\delta_{\mathrm{as}} \mathrm{CH}_{3}\right), 1348-1388\left(\delta_{\mathrm{s}} \mathrm{CH}_{3}\right), 1368-1360$ $\left(\delta_{1} \mathrm{CH}+\delta_{\mathrm{s}} \mathrm{CH}_{3}\right), 1315-1300\left(\delta_{2} \mathrm{CH}\right), 1270(\delta \mathrm{CH}+v \mathrm{COC}), 1215-1185\left(v_{\mathrm{as}} \mathrm{COC}+\mathrm{r}_{\mathrm{as}} \mathrm{CH}_{3}\right), 1130\left(\mathrm{r}_{\mathrm{as}} \mathrm{CH}_{3}\right), 1100-$ 1090 ( $\left.v_{\mathrm{s}} \mathrm{COC}\right), 1045$ (vC-CH$)_{3}, 960-950\left(\mathrm{rCH}_{3}+v \mathrm{CC}\right), 875-860$ (vC-COO), 760-740 $(\delta \mathrm{C}=0), 715-695(\gamma \mathrm{C}=\mathrm{O})$, $515\left(\delta_{1} \mathrm{C}-\mathrm{CH}_{3}+\delta \mathrm{CCO}\right), 415(\delta \mathrm{CCO}), 350\left(\delta_{2} \mathrm{C}-\mathrm{CH}_{3}+\delta \mathrm{COC}\right), 300-295\left(\delta \mathrm{COC}+\delta_{2} \mathrm{C}-\mathrm{CH}_{3}\right), 240(\tau \mathrm{CC})$

\section{PLA-Gl:}

${ }^{1} \mathrm{H}-\mathrm{NMR}: 5.24(1 \mathrm{H}, \mathrm{p},=\mathrm{CH}-\mathrm{O}-), 5.16\left(1 \mathrm{H}, \mathrm{q},-\mathrm{CH}\left(\mathrm{CH}_{3}\right)-\right), 4.35\left(1 \mathrm{H}, \mathrm{q},-\mathrm{CH}\left(\mathrm{CH}_{3}\right) \mathrm{OH}\right.$, end group), 4.27 (2H, d, $\left.-\mathrm{CH}_{2}-\mathrm{O}-\right), 1.59$ (3H, d, $\left.-\mathrm{CH}_{3}\right)$

${ }^{13} \mathrm{C}-\mathrm{NMR}: 169.7$ (-C(O)O-), 69.1 (-CH( $\left.\left(\mathrm{CH}_{3}\right)-\right), 62.1\left(-\mathrm{CH}_{2}-\mathrm{O}-\right), 16.7\left(-\mathrm{CH}_{3}\right)$

FTIR: $2997\left(v_{\mathrm{as}} \mathrm{CH}_{3}\right), 2947\left(\mathrm{v}_{\mathrm{s}} \mathrm{CH}_{3}\right), 2882(\mathrm{vCH}), 1760(\mathrm{vC}=\mathrm{O}), 1452\left(\delta_{\mathrm{as}} \mathrm{CH}_{3}\right), 1348-1388\left(\delta_{\mathrm{s}} \mathrm{CH}_{3}\right), 1368-1360$ $\left(\delta_{1} \mathrm{CH}+\delta_{\mathrm{s}} \mathrm{CH}_{3}\right), 1315-1300\left(\delta_{2} \mathrm{CH}\right), 1270(\delta \mathrm{CH}+v \mathrm{COC}), 1215-1185\left(v_{\mathrm{as}} \mathrm{COC}+\mathrm{r}_{\mathrm{as}} \mathrm{CH}_{3}\right), 1130\left(\mathrm{r}_{\mathrm{as}} \mathrm{CH}_{3}\right), 1100-$ 1090 ( $v_{\mathrm{s}} \mathrm{COC}$ ), 1045 (vC-CH$)_{3}$, 960-950 ( $\left.\mathrm{rCH}_{3}+v \mathrm{CC}\right), 875-860$ (vC-COO), 760-740 ( $\left.\delta \mathrm{C}=0\right), 715-695(\gamma \mathrm{C}=\mathrm{O})$, $515\left(\delta_{1} \mathrm{C}-\mathrm{CH}_{3}+\delta \mathrm{CCO}\right), 415(\delta \mathrm{CCO}), 350\left(\delta_{2} \mathrm{C}-\mathrm{CH}_{3}+\delta \mathrm{COC}\right), 300-295\left(\delta \mathrm{COC}+\delta_{2} \mathrm{C}^{-}-\mathrm{CH}_{3}\right), 240(\tau \mathrm{CC})$ 
Table 2. Cont.

\section{PLA-Pet:}

${ }^{1} \mathrm{H}-\mathrm{NMR}: 5.17\left(1 \mathrm{H}, \mathrm{q},-\mathrm{CH}\left(\mathrm{CH}_{3}\right)-\right)$, $4.36\left(1 \mathrm{H}, \mathrm{q},-\mathrm{CH}\left(\mathrm{CH}_{3}\right) \mathrm{OH}\right.$, end group), 1.60 (3H, d, - $\left.\mathrm{CH}_{3}\right)$

${ }^{13} \mathrm{C}-\mathrm{NMR}: 169.6$ (-C(O)O-), 69.1 (-CH( $\left.\left.\mathrm{CH}_{3}\right)-\right), 63.5\left(\mathrm{C}-\mathrm{CH}_{2} \mathrm{O}-\right), 33.4\left(\mathbf{C}-\mathrm{CH}_{2} \mathrm{O}-\right), 16.7\left(-\mathrm{CH}_{3}\right)$

FTIR: $2998\left(v_{\mathrm{as}} \mathrm{CH}_{3}\right), 2947\left(\mathrm{v}_{\mathrm{s}} \mathrm{CH}_{3}\right), 2883(\mathrm{vCH}), 1760(\mathrm{vC}=\mathrm{O}), 1453\left(\delta_{\mathrm{as}} \mathrm{CH}_{3}\right), 1348-1388\left(\delta_{\mathrm{s}} \mathrm{CH}_{3}\right), 1368-1360$ $\left(\delta_{1} \mathrm{CH}+\delta_{\mathrm{s}} \mathrm{CH}_{3}\right), 1315-1300\left(\delta_{2} \mathrm{CH}\right), 1270(\delta \mathrm{CH}+v \mathrm{COC}), 1215-1185\left(v_{\mathrm{as}} \mathrm{COC}+\mathrm{r}_{\mathrm{as}} \mathrm{CH}_{3}\right), 1132\left(\mathrm{r}_{\mathrm{as}} \mathrm{CH}_{3}\right), 1100-$ 1090 ( $\left.v_{\mathrm{s}} \mathrm{COC}\right), 1046\left(v \mathrm{C}-\mathrm{CH}_{3}\right), 960-950\left(\mathrm{rCH}_{3}+v \mathrm{CC}\right), 875-860$ (vC-COO), 760-740 $(\delta \mathrm{C}=0), 715-695(\gamma \mathrm{C}=\mathrm{O})$, $516\left(\delta_{1} \mathrm{C}-\mathrm{CH}_{3}+\delta \mathrm{CCO}\right), 415(\delta \mathrm{CCO}), 351\left(\delta_{2} \mathrm{C}-\mathrm{CH}_{3}+\delta \mathrm{COC}\right), 300-295\left(\delta \mathrm{COC}+\delta_{2} \mathrm{C}-\mathrm{CH}_{3}\right), 242(\tau \mathrm{CC})$

\section{Copolymers of LA and CL:}

${ }^{1} \mathrm{H}-\mathrm{NMR}: 5.15$ (1H, q, -CH( $\left.\left.\mathrm{CH}_{3}\right)-\right), 4.27$ (1H, q, - $\mathrm{CH}\left(\mathrm{CH}_{3}\right) \mathrm{OH}$, end group), 4.11 (2H, t, - $\left.\mathrm{CH}_{2} \mathrm{CH}_{2} \mathrm{OC}(\mathrm{O})-\mathrm{LA}\right)$, 4.03 (2H, t, - $\mathrm{CH}_{2} \mathrm{CH}_{2} \mathrm{OC}(\mathrm{O})-$ ), 3.67 (2H, t, $-\mathrm{CH}_{2} \mathrm{CH}_{2} \mathrm{OH}$, end group), 2.37 (2H, t, LA- $\mathrm{CH}_{2} \mathrm{CH}_{2} \mathrm{CH}_{2} \mathrm{CH} \mathbf{H}_{2} \mathrm{COO}-$ ), 2.29 (2H, t, $\left.-\mathrm{CH}_{2} \mathrm{CH}_{2} \mathrm{COO}-\right), 1.63\left(4 \mathrm{H}, \mathrm{m},-\mathrm{CH}_{2} \mathrm{CH}_{2} \mathrm{COO}-\right), 1.59$ (3H, d, $\left.-\mathrm{CH}_{3}\right), 1.34$ (2H, m, $\mathrm{CH}_{2} \mathrm{CH}_{2} \mathrm{CH}_{2} \mathrm{CH}_{2} \mathrm{CH}_{2}-$ ), and peaks of $\mathrm{Gl}$, Pet and PEG

Figure 1. ${ }^{1} \mathrm{H}-\mathrm{NMR}$ spectrum of the two-armed PCL (in $\mathrm{CDCl}_{3}$ ).

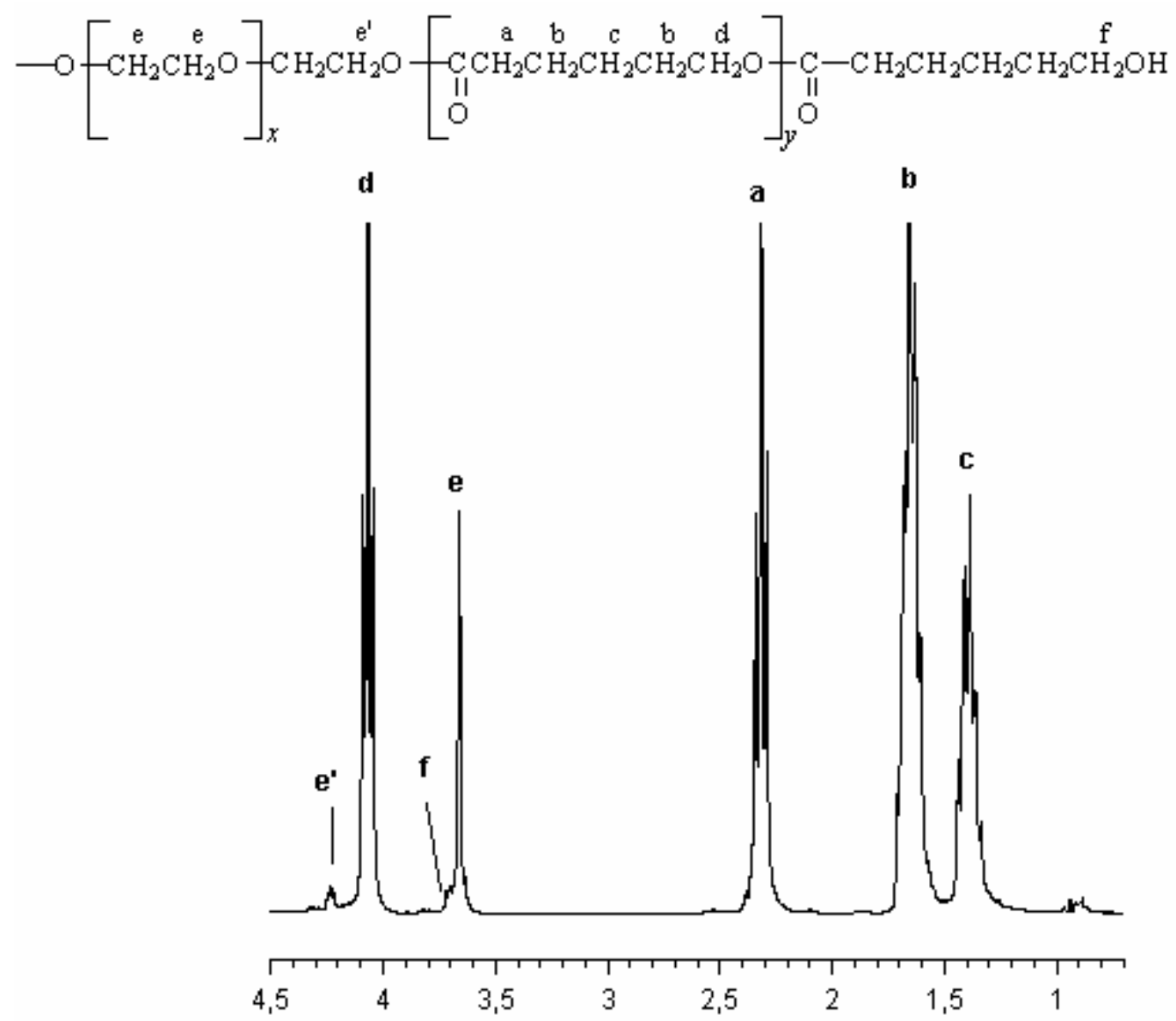

The MALDI-TOF mass spectra of obtained oligomers confirmed that the main product was starshaped oligoester terminated with hydroxyl group. The mass spectra also revealed a small fraction (presumably below 5 wt \%) of cyclic oligolactones. Figure 2 shows typical MALDI-TOF spectra of the polymeric products. 
Figure 2. MALDI-TOF spectrum of PLA synthesized in the presence of Pet and SnOct $_{2}$.

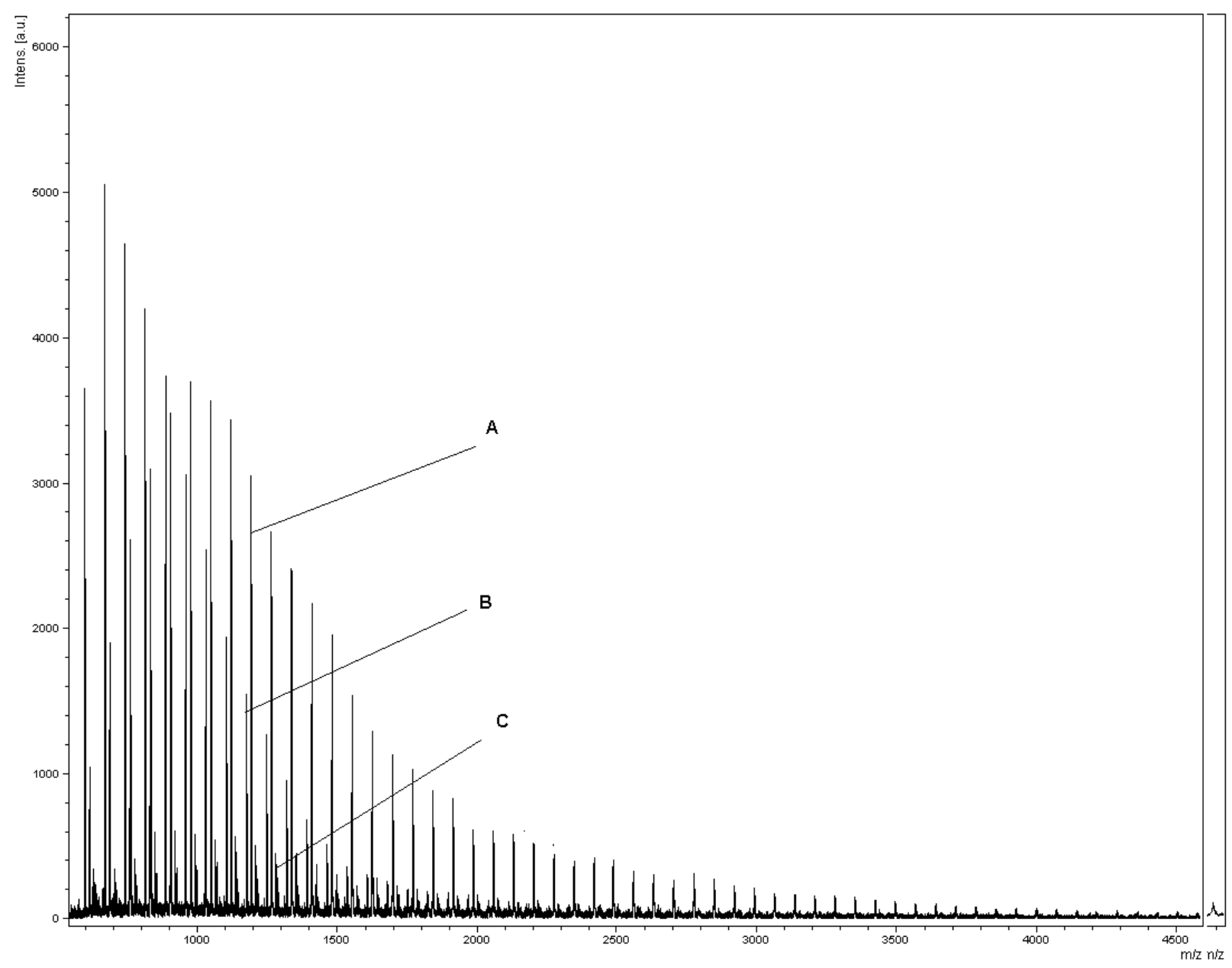

The MALDI-TOF spectra of PLA comprise three series of peaks. The main series of prominent peaks (A) corresponds to the PLA molecules terminated with a hydroxyl group (residual mass: $41 \mathrm{Da}$, $\mathrm{Na}^{+}$adduct), the second series of smaller peaks (B) also corresponds to the PLA molecules terminated with a hydroxyl group (residual mass: $57 \mathrm{Da}, \mathrm{K}^{+}$adduct) and the third series of low-intensity peaks (C) corresponds to cyclic molecules (residual mass: $23 \mathrm{Da}, \mathrm{Na}^{+}$adduct). Populations of PLA chains with both even and odd numbers of LA monomer units (m.u.) can be observed. The presence of the odd number of LA m.u. indicates that under the reaction conditions the polymer chain undergoes intermolecular transesterification, leading to the exchange of segments. This is a typical phenomenon for the polymerization of lactides [14]

In the MALDI-TOF spectra of PCL there are also three series of peaks. The most dominant one is characterized by a mass increment of $114 \mathrm{Da}$, which is equal to the mass of the repeating PCL unit. This series has been assigned to PCL terminated with a hydroxyl group (residual mass: $41 \mathrm{Da}, \mathrm{Na}^{+}$ adduct) (A). The second series of peaks also corresponds to PCL terminated with a hydroxyl group (residual mass: $57 \mathrm{Da}, \mathrm{K}^{+}$adduct) (B). In addition, the PCL mass spectrum contains a series of minor peaks corresponding to cyclic molecules (residual mass: $23 \mathrm{Da}, \mathrm{Na}^{+}$adduct) (C). The average molecular weights determined using MALDI-TOF MS were in the 1900-2500 and 1400-1600 Da ranges for PCL and PLA, respectively. 
The macromolecular prodrugs were obtained (Scheme 2) from the reactions of the two-, three- and four-arm, star-shaped PCL and PLA homopolymers, and the CL\&LA copolymers with norfloxacin (NOR).

Scheme 2. Synthesis of the polyester prodrugs of norfloxacin.<smiles>CCn1cc(C(=O)O)c(=O)c2cc(F)c(N3CCNCC3)cc21</smiles><smiles>CC[C@H](C)OOC(=O)c1cn(CC)c2cc(N3CCNCC3)c(F)cc2c1=O</smiles>

The chemical structures of the macromolecular prodrugs were confirmed by ${ }^{1} \mathrm{H}-$ and ${ }^{13} \mathrm{C}-\mathrm{NMR}$, and by IR studies. Typical proton NMR spectra of pure NOR and of the reaction products of the twoarmed hydroxyl terminated PCL with NOR are shown in Figures 3 and 4, respectively. All the prodrug spectra have revealed characteristic peaks of norfloxacin, indicating successful preparation of the polymer-NOR conjugate.

Figure 3. ${ }^{1} \mathrm{H}-\mathrm{NMR}$ spectrum of NOR (in DMSO).

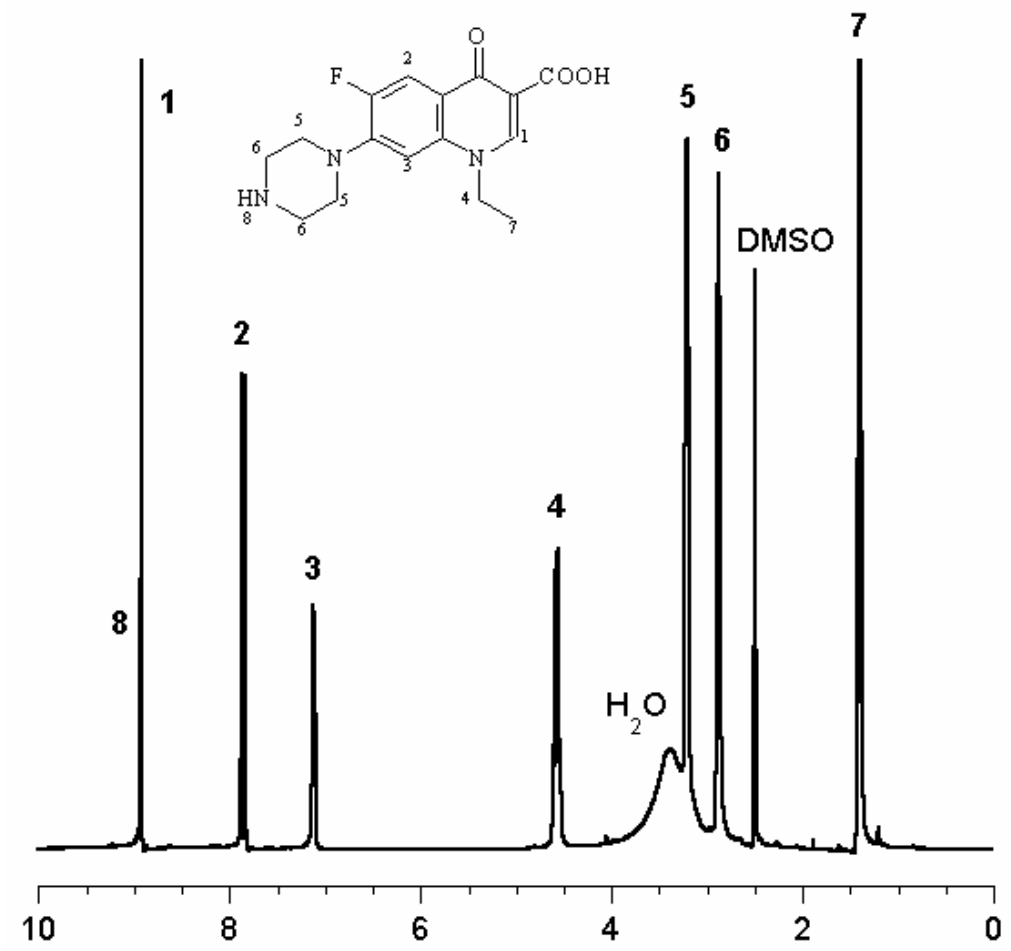


Figure 4. ${ }^{1} \mathrm{H}-\mathrm{NMR}$ spectrum of the prodrug PCL(PEG)-NOR (in DMSO).

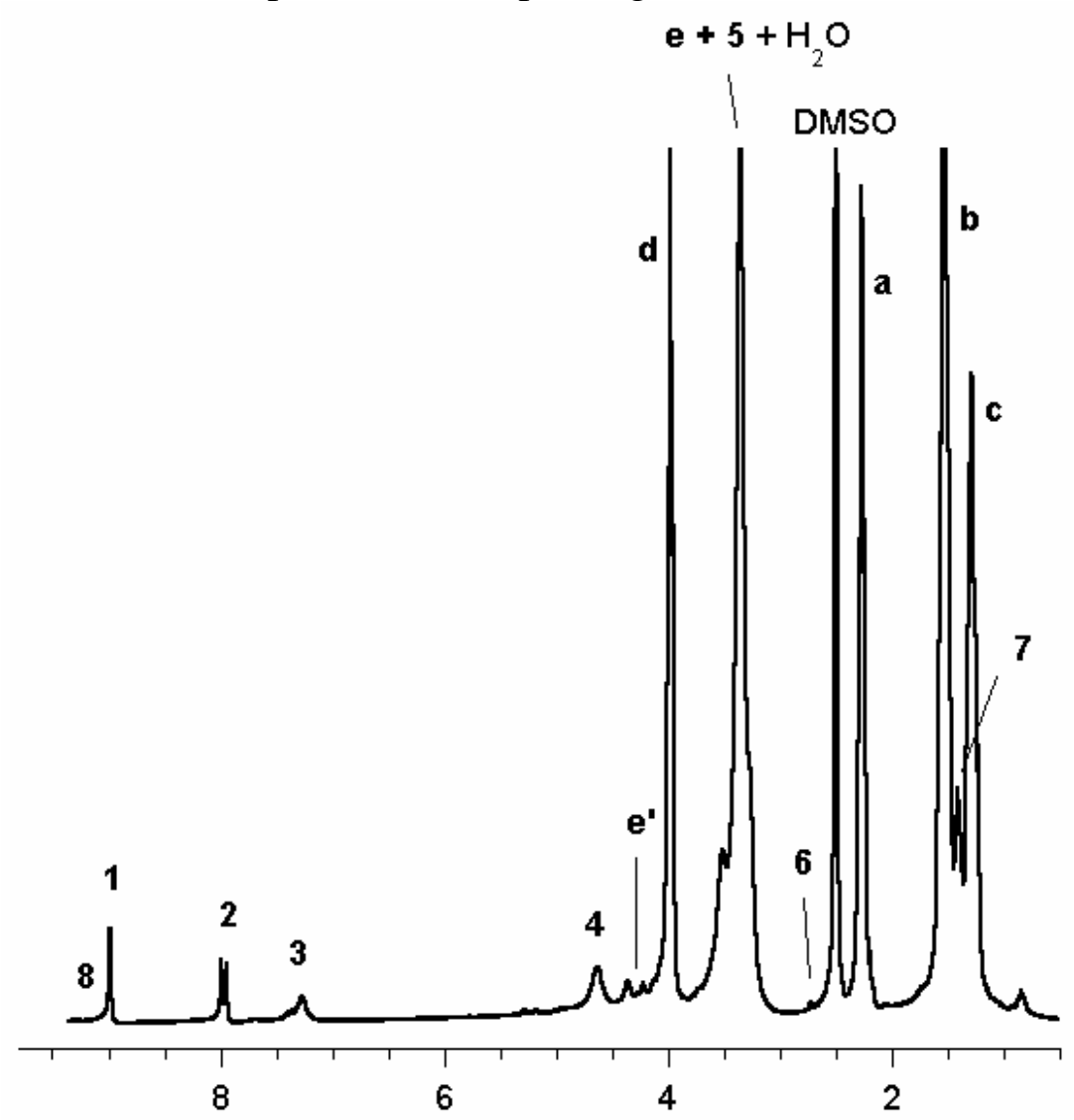

This work focused at the synthetic aspects of the NOR prodrugs. Kinetics of the NOR release from those polymers is still under study and will be presented in the next paper.

\section{Conclusions}

The two-, three- and four-arm, star-shaped poly( $\varepsilon$-caprolactone) and poly( $D, L$-lactide) homopolymers, and the copolymers of $\varepsilon$-caprolactone with $D, L$-lactide have been successfully used for the preparation of novel drug delivery systems of norfloxacin. The synthesis of those prodrugs was done in two steps. First, the ring-opening homo- or copolymerization of $\varepsilon$-caprolactone and $D$, $L$-lactide in the presence of initiators (poly(ethylene glycol), pentaerythritol or glycerol) and SnOct $_{2}$ as a catalyst was carried out. In the second step, the reaction of the polymer or copolymer with norfloxacin was performed. Our method of the synthesis is simple and effective. Thus obtained polyester prodrugs of norfloxacin are good potential candidates to be applied as drug delivery carriers. The latter application requires subsequent careful in vitro and in vivo examinations.

\section{Experimental}

\section{General}

$\varepsilon$-Caprolactone (CL) (2-Oxepanone, Aldrich 99\%) was dried and distilled before use over $\mathrm{CaH}_{2}$ at reduced pressure. 3,6-Dimethyl-1,4-dioxane-2,5-dione (D,L-LA) (rac-lactide, Aldrich 98\%) was 
crystallized from a mixture of dry toluene with hexane and dried under vacuum. Poly(ethylene glycol) (PEG) $(M n=400$, Serva Feinbiochemica), pentaerythritol (Pet) (Aldrich 99\%), glycerol (Gl) (Aldrich 99\%) and norfloxacin (NOR) (Aldrich 99\%) were exhaustively dried under vacuum prior use. Stannous octoate SnOct $_{2}$ (tin (II) 2-ethylhexanoate, Aldrich 95\%), dichloromethane and anhydrous methanol were used as received.

\section{Polymerization procedure}

Monomers (CL, LA), initiators (PEG, Pet, Gl) and the SnOct ${ }_{2}$ catalyst were placed in a $10 \mathrm{~mL}$ glass ampule under nitrogen atmosphere. The reaction vessel was then kept standing in a thermostated oil bath at $120{ }^{\circ} \mathrm{C}$ over $48 \mathrm{~h}$ (Table 1 ). When the reaction time was completed, the cold reaction product was dissolved in $\mathrm{CH}_{2} \mathrm{Cl}_{2}$, precipitated from cold methanol with diluted hydrochloric acid (to wash out the catalyst residue) and dried under vacuum for $72 \mathrm{~h}$.

\section{Prodrugs synthesis}

The prodrugs were prepared under nitrogen atmosphere at room temperature immediately before use. The polyesters were dissolved in $\mathrm{CH}_{2} \mathrm{Cl}_{2}(1 \mathrm{~g} / 50 \mathrm{~mL})$ and this solution was placed in a $150 \mathrm{~mL}$ three-necked flask equipped with a stirrer and addtion funnel. A solution of NOR in $\mathrm{CH}_{2} \mathrm{Cl}_{2}(2 \mathrm{~g} / 50 \mathrm{~mL})$ was placed in the funnel and added dropwise into the reactor, while the reaction mixture was vigorously stirred. After the addition procedure was completed, the reaction mixture was left stirring for an additional $8 \mathrm{~h}$, then it was washed with dilute hydrochloric acid and water. The washing was continued to fully remove any unreacted drug. The prodrugs isolated from the solution (organic phase) were kept under vacuum at room temperature for no more than one week.

\section{Measurements}

The polymerization products were characterized by means of ${ }^{1} \mathrm{H}$ - and ${ }^{13} \mathrm{C}-\mathrm{NMR}$ (Varian $300 \mathrm{MHz}$ ), and FTIR spectroscopy (Spectrum 1000, Perkin Elmer). The NMR spectra were recorded in $\mathrm{CDCl}_{3}$ or DMSO- $\mathrm{d}_{6}$. The IR spectra were recorded from $\mathrm{KBr}$ pellets. Relative molecular mass and molecular mass distributions were determined by MALDI-TOF MS and GCP techniques. The MALDI-TOF spectra were measured in the linear mode on a Kompact MALDI 4 Kratos analytical spectrometer using a nitrogen gas laser with 2-[(4-hydroxyphenyl)diazenyl] benzoic acid (HABA) as a matrix. GPC measurements were made at $25^{\circ} \mathrm{C}$ in the tetrahydrofuran solution using Shimadzu C-R4 Chromatopac apparatus. The molecular weights were calibrated with polystyrene standards.

\section{Norfloxacin:}

${ }^{1} \mathrm{H}-\mathrm{NMR}\left(\mathrm{CDCl}_{3}, \mathrm{ppm}\right):$ 1.61, 3.14, 3.31, 4.33, 6.84, 8.07, 8.69, 8.73; (DMSO, ppm): 1.40, 2.88, 3.21, 4.56, 7.13, 7.87, 8.93, 9.03; ${ }^{13} \mathrm{C}-\mathrm{NMR}\left(\mathrm{CDCl}_{3}, \mathrm{ppm}\right): 14.7,46.1,49.9,51.3,103.9,108.6,113.2$, 137.3, 147.3, 152.1, 155.5, 167.5, 177.3; FTIR ( $\left.\mathrm{cm}^{-1}\right)$ : $3470(v O H), 1710$ (vCO), 1624 (vC=C i C=N), 
$1452\left(\delta \mathrm{CH}_{2} \mathrm{i} \omega \mathrm{CH}_{2}\right), 1194(\delta \mathrm{CH}, \gamma \mathrm{CH}$ i vC-O), 1102 (benzene + pyridine ring breathing), 801 (vC-N i $\left.\delta \mathrm{CH}_{2}\right)$;

\section{Acknowledgements}

This work was supported by the Medical University of Warsaw within the young researcher and student grants: FW23/WB3/07 and FW23/NM1/07, respectively.

\section{References}

1. Jagur-Grodzinski, J. Biomedical application of functional polymers. React. Funct. Polym. 1999, 39, 99-138.

2. Uhrich, K. E.; Cannizzaro, S. M.; Langer, R. S.; Shakesheff K., M. Polymeric systems for controlled drug release. Chem. Rev. 1999, 99, 3181-3198.

3. Veronese, F.M.; Morpurgo, M. Bioconjugation in pharmaceutical chemistry. Farmaco 1999, 54, 497-516.

4. Hoste, K; De Winne, K; Schacht. Polymeric prodrugs. Int. J. Pharm. 2004, 277, 119-131.

5. $\quad$ Ouchi, T.; Ohya Y. Macromolecular prodrugs. Prog. Polym. Sci. 1995, 20, 211-257.

6. Garnett, M.C. Targeted drug conjugates: principles and progress. Adv. Drug Del. Rev. 2001, 53, 171-216.

7. Merkli, A.; Tabatabay, C., Gurny, R; Heller, J. Biodegradable polymers for the controlled release of ocular drugs. Prog. Polym. Sci. 1998, 23, 563-580.

8. Takakura, Y.; Hashida, M. Macromolecular drug carrier systems in cancer chemotherapy: macromolecular prodrugs. Crit. Rev. Oncol./Hematol. 1995, 18, 207-231.

9. Järvinen, T.; Järvinen, K. Prodrugs for improved ocular delivery. Adv. Drug Del. Rev. 1996, 19, 203-224.

10. Ueda, H; Tabata, Y. Polyhydroxyalkanonate derivatives in current clinical applications and trials. Adv. Drug Del. Rev. 2003, 55, 501-518.

11. Khandare, J; Minko, T. Polymer-drug conjugates: Progress in polymeric prodrugs. Prog. Polym. Sci. 2006, 31, 359-397.

12. Sobczak, M.; Olędzka E.; Kolodziejski, W.; Kuźmicz R. Pharmaceutical application of polymers. Polimery 2007, 52, 411-420.

13. Albertsson A-Ch., Varma I.V. Recent developments in ring opening polymerization of lactones for biomedical applications. Biomacromolecules 2003, 4, 1466-1486.

14. Florjańczyk, Z.; Plichta, A.; Sobczak, M. Ring opening polymerization initiated by methylaluminoxane/AlMe3 complexes. Polymer 2006, 47, 1081-1090.

15. Marcilla, R.; de Geus, M.; Mecerreyes, D.; Duxbury, Ch. J.; Koning, C. E.; Heise, A. Enzymatic polyester synthesis in ionic liquids. Eur. Polym. J. 2006, 42, 1215-1221.

16. He, F.; Li, S.; Garreau, H.; Vert, M.; Zhuo, R. Enzyme-catalyzed polymerization and degradation of copolyesters of $\varepsilon$-caprolactone and $\gamma$-butyrolactone. Polymer 2005, 46, 12682-12688.

17. Duda, A; Biela, T.; Kowalski, A; Lubiszowski, J. Amines as (co)initiators of cyclic esters' polymerization. Polimery 2005, 50, 501-508. 
18. Cai, Q.; Zhao, Y.; Bei, J.; Xi, F.; Wang, S. Synthesis and Properties of Star-Shaped Polylactide Attached to Poly(Amidoamine) Dendrimer. Biomacromolecules 2003, 4, 828-834.

19. Martin, E; Dubois, P.; Jerome, R. In Situ" Formation of Yttrium Alkoxides: A Versatile and Efficient Catalyst for the ROP of $\varepsilon$-Caprolactone. Macromolecules 2003, 36, 5934-5941.

20. Storey, R. F.; Sherman, J. W. Kinetics and mechanism of the stannous octoate-catalyzed bulk polymerization of $\varepsilon$-caprolactone. Macromolecules 2002, 35, 1504-1512.

21. Sanda, F.; Sanada, H.; Shibasaki, Y.; Endo, T. Star polymer synthesis from $\varepsilon$-caprolactone utilizing polyol/protonic acid initiator. Macromolecules 2002, 35, 680-683.

22. Connor, E. F.; Nyce G. W.; Myers, M.; Moeck, A.; Hedrick, J. L. First example of N-heterocyclic carbenes as catalysts for living polymerization: Organocatalytic ring-opening polymerization of cyclic esters. J. Am. Chem. Soc. 2002, 124, 914-915.

23. Okada, M. Chemical syntheses of biodegradable polymers. Prog. Polym. Sci. 2002, 27, 87-133.

24. Kobayashi, S. ; Uyama, H.; Kimura, S. Enzymatic Polymerization. Chem. Rev. 2001, 101, 37933818.

25. Kowalski, A.; Duda, A.; Penczek, S. Kinetics and mechanism of cyclic esters polymerization initiated with tin(II) octoate. 3. Polymerization of L,L-dilactide. Macromolecules 2000, 33, 73597370 .

26. Shibasaki, Y.; Sanada, H.; Ypkoi, M.; Sanda, F.; Endo, T. Activated monomer cationic polymerization of lactones and the application to well-defined block copolymer synthesis with seven-membered cyclic carbonate. Macromolecules 2000, 33, 4316-4320.

27. Divakar, S. Porcine pancreas lipase catalyzed ring-opening polymerization of $\varepsilon$-Caprolactone. $J$. Macromol. Sci. Pure Appl. Chem. 2004, A41, 537-546.

28. Namekawa, S.; Suda, S.; Uyama, H.; Kobayashi, S. Lipase-catalyzed ring-opening polymerization of lactones to polyesters and its mechanistic aspects. Int. J. Biol. Macromol. 1999, 25, 145-151.

29. Zejca A.; Gorczyca M. Chemia leków; PZWL: Warsaw, 2002.

30. Hu, W.-X.; Zhou, W.; Xia, Ch.-N.; Wen, X. Synthesis and anticancer activity of thiosemicarbazones. Bioorg. Med. Chem. Lett. doi:10.1016/j.bmcl.2006.01.048, in press.

31. Jeon, H.-J.; Jeong, Y.-I.; Jang, M.-K.; Park, Y.-H.; Nah, J.-W. Effect of solvent on the preparation of surfactant-free poly(DL-lactide-co-glycolide) nanoparticles and norfloxacin release characteristics. Int. J. Pharmaceut. 2000, 207, 99-108.

Sample availability: Contact the authors.

(C) 2008 by MDPI (http://www.mdpi.org). Reproduction is permitted for noncommercial purposes. 